\title{
Synthesis, Characterization, and In Vitro Cytotoxic Activities of Benzaldehyde Thiosemicarbazone Derivatives and Their Palladium(II) and Platinum(II) Complexes against Various Human Tumor Cell Lines
}

\author{
Wilfredo Hernández, ${ }^{1}$ Juan Paz, ${ }^{1}$ Abraham Vaisberg, ${ }^{2}$ Evgenia Spodine, ${ }^{3}$ \\ Rainer Richter, ${ }^{4}$ and Lothar Beyer ${ }^{4}$ \\ ${ }^{1}$ Facultad de Ingeniería Industrial, Universidad de Lima, Avenue Javier Prado Este Cda 46, Monterrico-Santiago de Surco, \\ Lima 33, Peru \\ ${ }^{2}$ Facultad de Ciencias y Filosofía, Laboratorio de Investigación y Desarrollo, Universidad Peruana Cayetano Heredia, \\ Avenue Honorio Delgado 430, Urb. Ingeniería-San Martín de Porras, Lima 31, Peru \\ ${ }^{3}$ Facultad de Ciencias Químicas y Farmacéuticas and CIMAT, Universidad de Chile, Santiago 8380000, Chile \\ ${ }^{4}$ Fakultät für Chemie und Mineralogie, Universität Leipzig, Johannisallee 29, 04103 Leipzig, Germany
}

Correspondence should be addressed to Wilfredo Hernández, whernandez79@yahoo.es

Received 26 June 2008; Accepted 17 October 2008

Recommended by Igor Fritsky

The palladium(II) bis-chelate $\mathrm{Pd}\left(\mathrm{L}^{1-3}\right)_{2}$ and platinum(II) tetranuclear $\mathrm{Pt}_{4}\left(\mathrm{~L}^{4}\right)_{4}$ complexes of benzaldehyde thiosemicarbazone derivatives have been synthesized, and characterized by elemental analysis and IR, FAB (+)-mass and NMR $\left({ }^{1} \mathrm{H},{ }^{13} \mathrm{C}\right)$ spectroscopy. The complex $\mathrm{Pd}\left(\mathrm{L}^{2}\right)_{2}\left[\mathrm{HL}^{2}=m\right.$-CN-benzaldehyde thiosemicarbazone $]$ shows a square-planar geometry with two deprotonated ligands (L) coordinated to $\mathrm{Pd}^{\mathrm{II}}$ through the nitrogen and sulphur atoms in a trans arrangement, while the complex $\mathrm{Pt}_{4}\left(\mathrm{~L}^{4}\right)_{4}$ $\left[\mathrm{HL}^{4}=4\right.$-phenyl-1-benzaldehyde thiosemicarbazone $]$ has a tetranuclear geometry with four tridentate ligands coordinated to four $\mathrm{Pt}^{\mathrm{II}}$ ions through the carbon (aromatic ring), nitrogen, and sulphur atoms where the ligands are deprotonated at the $\mathrm{NH}$ group. The in vitro antitumor activity of the ligands and their complexes was determined against different human tumor cell lines, which revealed that the palladium(II) and platinum(II) complexes are more cytotoxic than their ligands with IC $_{50}$ values at the range of $0.07-3.67 \mu \mathrm{M}$. The tetranuclear complex $\mathrm{Pt}_{4}\left(\mathrm{~L}^{4}\right)_{4}$, with the phenyl group in the terminal amine of the ligand, showed higher antiproliferative activity $\left(\mathrm{CI}_{50}=0.07-0.12 \mu \mathrm{M}\right)$ than the other tested palladium(II) complexes.

Copyright (c) 2008 Wilfredo Hernández et al. This is an open access article distributed under the Creative Commons Attribution License, which permits unrestricted use, distribution, and reproduction in any medium, provided the original work is properly cited.

\section{INTRODUCTION}

The synthesis of transition metal complexes with thiosemicarbazone ligands has been receiving considerable attention due to the pharmacological properties of both ligands and complexes [1-3]. Thiosemicarbazone derivatives exhibit a great variety of biological activities, such as antitumor [4], antifungal $[5,6]$, antibacterial $[6,7]$, and antiviral $[8]$ properties.

The deprotonated thiosemicarbazone ligands usually coordinate to platinum, palladium, copper, ruthenium, and osmium through oxygen, nitrogen, and sulphur donor atoms in their $(\mathrm{N}, \mathrm{S})$ bidentate form or $(\mathrm{N}, \mathrm{N}, \mathrm{S}$ or $\mathrm{O}, \mathrm{N}, \mathrm{S})$ tridentate form, to form metallic complexes of different molecular geometry [9-11].

The square planar platinum(II) and palladium(II) complexes of $\mathrm{M}(\mathrm{HL}) \mathrm{Cl}_{2}$ and $\mathrm{M}(\mathrm{L}) \mathrm{Cl}$ type with thiosemicarbazone ligands derived from phenylacetaldehyde and 2formylpyridine showed high cytotoxicity in vitro against HL60 leukemia and P388 mouse leukemia cell lines [12], while platinum(II) and palladium(II) binuclear complexes with p-isopropylbenzaldehyde thiosemicarbazone ligands exhibit strong cytotoxic activities on mouse tumor cell growth inhibition $[4,13]$.

On the other hand, $\mathrm{C}, \mathrm{N}, \mathrm{S}$ thiosemicarbazone ligands can also be coordinated to palladium(II) to form complexes with 


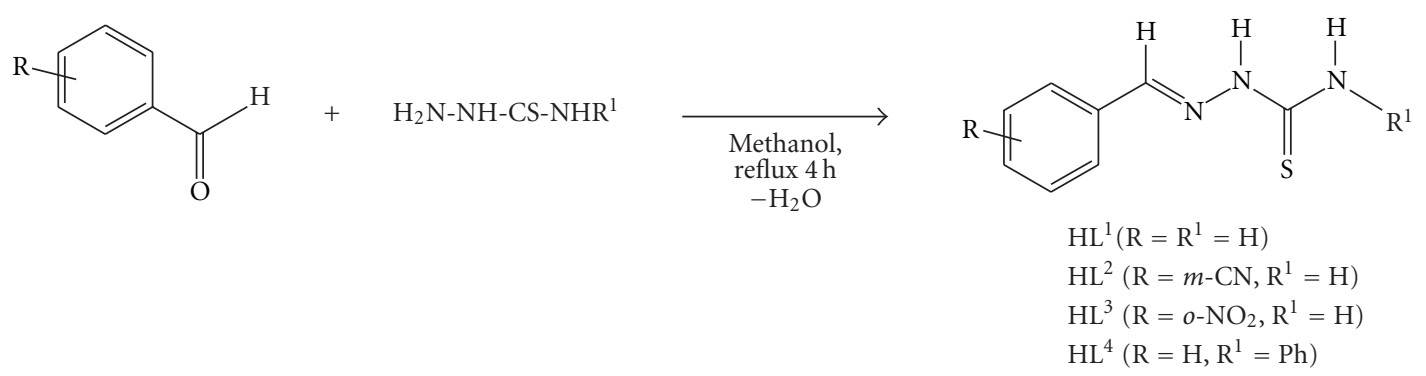

Scheme 1: Synthesis of the benzaldehyde thiosemicarbazone and 4-phenyl-1-benzaldehyde thiosemicarbazone ligands.

two fused five-membered chelate rings containing a carbonmetal $\sigma$ bond [14]. Although there is little information about the antitumor activity of these tetranuclear complexes, their pharmacological applications could be relevant.

As part of our continuing investigations about metal complexes with ligands derived from thiourea [15-19] such as thiosemicarbazones, we report here the synthesis, characterization, and antitumor activity of palladium(II) bis-chelates $\operatorname{Pd}\left(\mathrm{L}^{1-3}\right)_{2}$ and platinum(II) tetranuclear complex $\mathrm{Pt}_{4}\left(\mathrm{~L}^{4}\right)_{4}$ with benzaldehyde thiosemicarbazone and 4-phenyl-1-benzaldehyde thiosemicarbazone ligands, R$\mathrm{PhCH}=\mathrm{N}-\mathrm{NH}-\mathrm{C}(=\mathrm{S})-\mathrm{NHR}^{1}, \mathrm{HL}^{1}\left(\mathrm{R}, \mathrm{R}^{1}=\mathrm{H}\right), \mathrm{HL}^{2}(\mathrm{R}=m-\mathrm{CN}$, $\left.\mathrm{R}^{1}=\mathrm{H}\right), \mathrm{HL}^{3}\left(\mathrm{R}=o-\mathrm{NO}_{2}, \mathrm{R}^{1}=\mathrm{H}\right)$, and $\mathrm{HL}^{4}\left(\mathrm{R}=\mathrm{H}, \mathrm{R}^{1}=\mathrm{Ph}\right)$.

\section{EXPERIMENTAL}

\subsection{Materials and measurements}

Chemicals were reagent grade. Palladium(II) bis(acetylacetonate), ammonium tetrachloroplatinate, thiosemicarbazide, 4-phenyl-thiosemicarbazide, benzaldehyde, $m$ - $C N$ benzaldehyde, and $\mathrm{o}-\mathrm{NO}_{2}$-benzaldehyde were purchased from Aldrich. Melting points were determined on a Büchi melting point B-545 apparatus. Elemental analyses were determined on a Fisons-Carlo Erba Elemental Microanalyzer. The infrared (IR) spectra were recorded in solid state ( $\mathrm{KBr}$ pellets) on a Bruker FT-IR IFS 55 Equinox spectrophotometer in the $4000-400 \mathrm{~cm}^{-1}$ range. The $\mathrm{FAB}(+)$ mass spectra were recorded on a ZAB-HSQ (V.G. Analytical Ltd. Floats Roads, Wythenshawe, Manchester, England) spectrometer, using 3-nitrobenzyl alcohol as the matrix. The ${ }^{1} \mathrm{H}(300 \mathrm{MHz})$ and ${ }^{13} \mathrm{C}(75.5 \mathrm{MHz}) \mathrm{NMR}$ spectra were recorded on a Bruker Advance DRX 300 spectrometer at $300 \mathrm{~K}$, using DMSO- $\mathrm{d}_{6}$ as solvent. The chemical shifts $(\delta)$ in ppm were measured relative to tetramethylsilane (TMS).

\subsection{Synthesis of the ligands}

The thiosemicarbazone derivatives (HL) were prepared according to the literature [20] as shown in Scheme 1.

\section{General method}

To a hot solution of thiosemicarbazide $(1.82 \mathrm{~g}, 20 \mathrm{mmol})$ or 4-phenylthiosemicarbazide $(3.3 \mathrm{~g}, 20 \mathrm{mmol})$ in $160 \mathrm{~mL}$, methanol was added dropwise a solution of the corresponding benzaldehyde $(20 \mathrm{mmol})$ in $70 \mathrm{~mL}$ methanol during 30 minutes. The mixture was stirred and refluxed for 4 hours, it was filtered and the filtrate was concentrated to half the volume under reduced pressure. After a slow evaporation of the concentrate at room temperature, crystals were collected by filtration, washed with cold ethanol, and dried in vacuo. For ligand $\mathrm{HL}^{4}$, the filtrate was kept in the refrigerator and after several hours small rectangular crystals were obtained. These crystals were suitable for structure analysis by X-ray diffraction.

\subsubsection{Benzaldehyde thiosemicarbazone $\left(H L^{1}\right)$}

Colorless crystals. Yield $80 \%$, m.p. $167-169^{\circ} \mathrm{C}$. Anal. Calc. For $\mathrm{C}_{8} \mathrm{H}_{9} \mathrm{~N}_{3} \mathrm{~S}$ (179,2 g/mol): C, 53.6\%; H, 5.1\%; N, 23.4\%; S, $17.9 \%$. Found: C, 53.5\%; H, 5.3\%; N, 23.5\%; S, $17.7 \%$. FAB(+)-MS: m/z $179\left(\mathrm{M}^{+}, 70 \%\right)$; IR $\left(\mathrm{KBr}, \mathrm{cm}^{-1}\right): \nu\left(\mathrm{NH}_{2}\right)$ 3400 , 3380; $v(\mathrm{NH}) 3250 ; \nu(\mathrm{C}=\mathrm{N})$ 1600; $v(\mathrm{C}=\mathrm{S}) 885 .{ }^{1} \mathrm{H}-$ NMR (DMSO-d D $\left._{6}\right): \delta .78$ (d, 2 $\left.\mathrm{H}_{\text {ortho }}, \mathrm{Ph}, \mathrm{J}=6.8 \mathrm{~Hz}\right), 7.39$ $\left(\mathrm{t}, 2 \mathrm{H}_{\text {meta }}, \mathrm{Ph}, \mathrm{J}=7.2 \mathrm{~Hz}\right), 7.40\left(\mathrm{t}, 1 \mathrm{H}_{\text {para }}, \mathrm{Ph}, \mathrm{J}=7.2 \mathrm{~Hz}\right)$; $8.05(\mathrm{~s}, 1 \mathrm{H}, \mathrm{HC}=\mathrm{N}) ; 8.19,7.98\left(\mathrm{~d}, 2 \mathrm{H}, \mathrm{NH}_{2}\right) ; 11.42(\mathrm{~s}, 1 \mathrm{H}$, $=\mathrm{N}-\mathrm{NH}) .{ }^{13} \mathrm{C}-\mathrm{NMR}\left(\mathrm{DMSO}_{\mathrm{d}}\right): \delta 128.65,127.29,129.83$, $134.18(\mathrm{Ph}) ; 142.28(\mathrm{HC}=\mathrm{N}) ; 178.0(\mathrm{C}=\mathrm{S})$.

\subsection{2. m-cyanobenzaldehyde thiosemicarbazone $\left(\mathrm{HL}^{2}\right)$}

Colorless crystals. Yield 76\%, m.p. 203-204 ${ }^{\circ}$ C. Anal. Calc. For $\mathrm{C}_{9} \mathrm{H}_{8} \mathrm{~N}_{4} \mathrm{~S}$ (204,3 g/mol): C, 52.9\%; H, 3.9\%; N, 27.4\%; S, $15.7 \%$. Found: C, 52.8\%; H, 3.7\%; N, 27.6\%; S, $15.5 \%$; FAB(+)-MS: m/z $205\left(\mathrm{MH}^{+}, 100 \%\right)$; IR $\left(\mathrm{KBr}, \mathrm{cm}^{-1}\right): v\left(\mathrm{NH}_{2}\right)$ 3410, 3397; $v(\mathrm{NH}) 3236 \nu(\mathrm{CN})$ 2233; $v(\mathrm{C}=\mathrm{N})$ 1596; $v(\mathrm{C}=\mathrm{S})$ 880. ${ }^{1} \mathrm{H}-\mathrm{NMR}\left(\mathrm{DMSO}_{\mathrm{d}}\right.$ ): $\delta 7.81,7.79$ (s, d, $2 \mathrm{H}_{\text {ortho }}, \mathrm{Ph}, \mathrm{J}$ $=5.9 \mathrm{~Hz}) ; 7.58\left(\mathrm{t}, 1 \mathrm{H}_{\text {meta }}, \mathrm{Ph}, \mathrm{J}=7.7 \mathrm{~Hz}\right) ; 7.83\left(\mathrm{t}, 1 \mathrm{H}_{\text {para }}, \mathrm{Ph}, \mathrm{J}\right.$ $=5.7 \mathrm{~Hz}) ; 8.03(\mathrm{~s}, 1 \mathrm{H}, \mathrm{HC}=\mathrm{N}) ; 8.31,8.26\left(\mathrm{~d}, 2 \mathrm{H}, \mathrm{NH}_{2}\right) ; 11.60$ $(\mathrm{s}, 1 \mathrm{H},=\mathrm{N}-\mathrm{NH}) .{ }^{13} \mathrm{C}-\mathrm{NMR}\left(\mathrm{DMSO}-\mathrm{d}_{6}\right): \delta 129.87,118.6$, 135.69, 132.32, $132.68(\mathrm{Ph}) ; 111.97(\mathrm{CN}) ; 139.66(\mathrm{HC}=\mathrm{N})$; 178.35 (C=S).135.69, 130.15.

\subsection{3. o-nitrobenzaldehyde thiosemicarbazone $\left(H L^{3}\right)$}

Yellow crystals. Yield 90\%, m.p. $214-215^{\circ}$ C. Anal. Calc. For $\mathrm{C}_{8} \mathrm{H}_{8} \mathrm{O}_{2} \mathrm{~N}_{4} \mathrm{~S}$ (224.3 g/mol): C, 42.9\%; H, 3.6\%; N, 24.9\%; S, $14.3 \%$. Found: C, $42.6 \% ; \mathrm{H}, 3.5 \% ; \mathrm{N}, 24.6 \%$;, $14.1 \%$. FAB(+)-MS: m/z $226\left(\mathrm{MH}^{+}, 100 \%\right)$; IR $\left(\mathrm{KBr}, \mathrm{cm}^{-1}\right): v\left(\mathrm{NH}_{2}\right)$ 


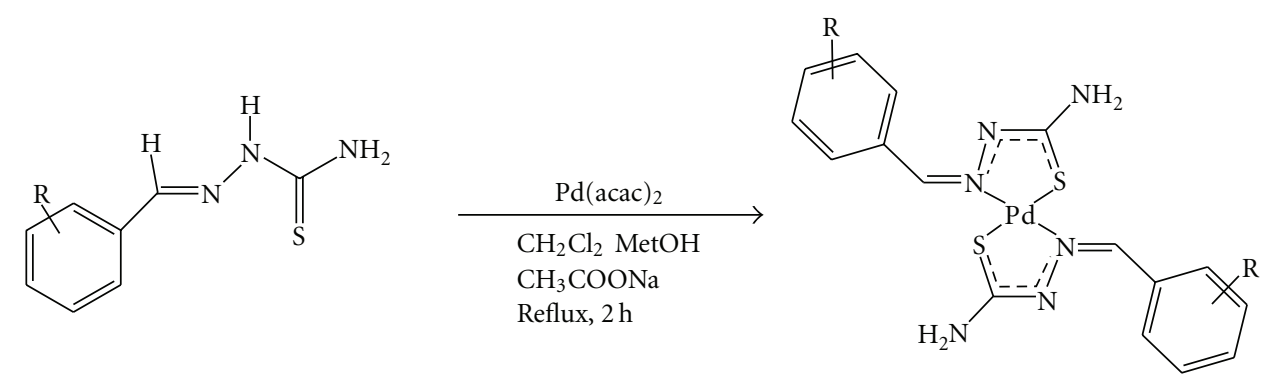

$\operatorname{Pd}\left(\mathrm{L}^{1}\right)_{2}(\mathrm{R}=\mathrm{H})$

$\operatorname{Pd}\left(\mathrm{L}^{2}\right)_{2}(\mathrm{R}=m-\mathrm{CN})$

$\operatorname{Pd}\left(\mathrm{L}^{3}\right)_{2}\left(\mathrm{R}=o-\mathrm{NO}_{2}\right)$

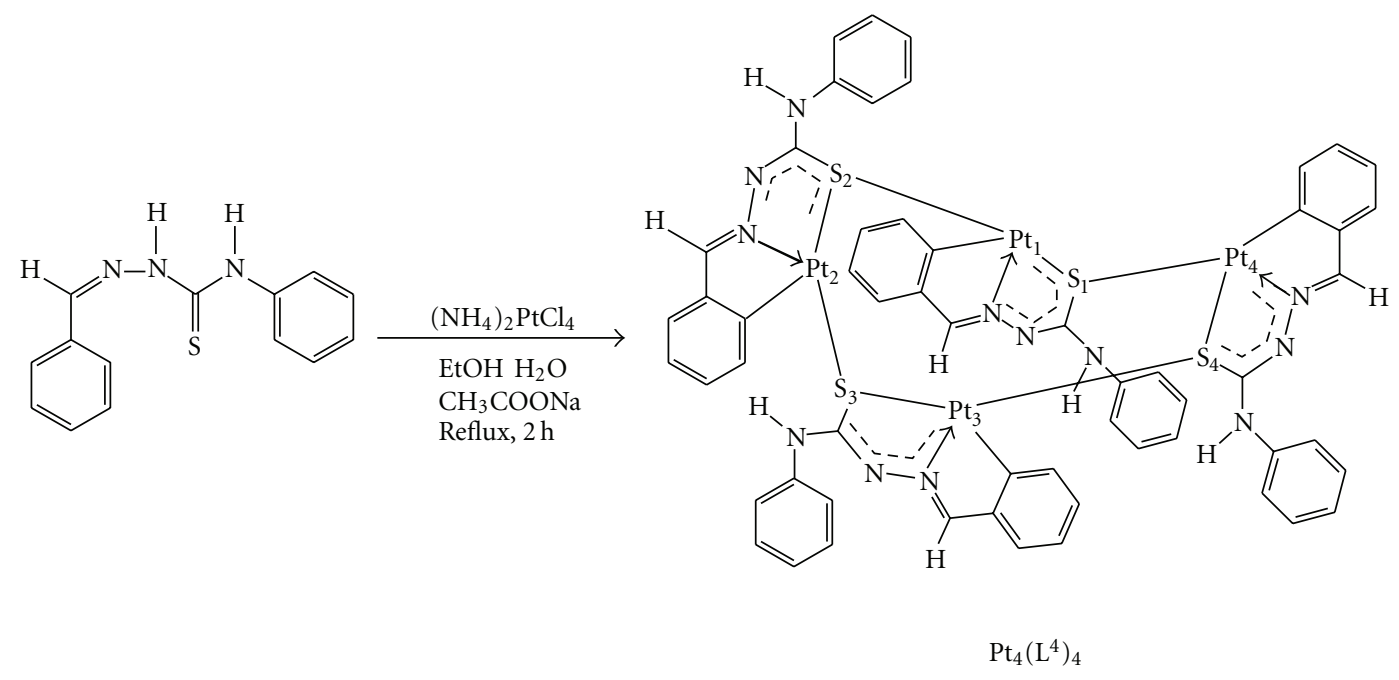

Scheme 2: Synthesis of the palladium(II) bis-chelate complexes and the platinum(II) tetranuclear complex.

3421, 3370; $v(\mathrm{NH}) 3240 ; \nu(\mathrm{C}=\mathrm{N}) 1602 ; \nu(\mathrm{C}=\mathrm{S}) 890 .{ }^{1} \mathrm{H}-$ NMR (DMSO- $\left.\mathrm{d}_{6}\right): \delta 7.58$ (d, $\left.1 \mathrm{H}_{\text {ortho }}, \mathrm{Ph}, \mathrm{J}=6.9 \mathrm{~Hz}\right) ; 8.02$, $7.73\left(\mathrm{~d}, \mathrm{~d}, 2 \mathrm{H}_{\text {meta }}, \mathrm{Ph}, \mathrm{J}=7.8 \mathrm{~Hz}\right) ; 7.61\left(\mathrm{t}, 1 \mathrm{H}_{\text {para }}, \mathrm{Ph}, \mathrm{J}\right.$ $=6.7 \mathrm{~Hz}) ; 8.12(\mathrm{~s}, 1 \mathrm{H}, \mathrm{HC}=\mathrm{N}) ; 8.45,8.41\left(\mathrm{~d}, 2 \mathrm{H}, \mathrm{NH}_{2}\right) ; 11.73$ $(\mathrm{s}, 1 \mathrm{H},=\mathrm{N}-\mathrm{NH}) .{ }^{13} \mathrm{C}-\mathrm{NMR}\left(\mathrm{DMSO}_{\mathrm{d}}\right): \delta 124.54,137.24$, 130.36, 133.36, 128.46, $128.33(\mathrm{Ph}) ; 148.29(\mathrm{HC}=\mathrm{N}) ; 178.49$ $(\mathrm{C}=\mathrm{S})$.

\subsubsection{4-phenyl-1-benzaldehyde thiosemicarbazone $\left(H L^{4}\right)$}

Yellow crystals. Yield 75\%, m.p. 192-194 ${ }^{\circ} \mathrm{C}$. Anal. Calc. For $\mathrm{C}_{14} \mathrm{H}_{13} \mathrm{~N}_{3} \mathrm{~S}$ (255.3 g/mol): C, 65.9\%; H, 5.1\%; N, 16.5\%; S, 12.5\%. Found: C, 65.4\%; H, 5.3\%; N, 16.7\%; S, $12.6 \%$. FAB(+)-MS: m/z $255\left(\mathrm{M}^{+}, 48 \%\right) ; \mathrm{IR}\left(\mathrm{KBr}, \mathrm{cm}^{-1}\right): v(\mathrm{NH})$ 3245; $v(\mathrm{C}=\mathrm{N}) 1625 ; \nu(\mathrm{C}=\mathrm{S}) 915 .{ }^{1} \mathrm{H}-\mathrm{NMR}\left(\mathrm{DMSO}-\mathrm{d}_{6}\right): \delta$ $7.42\left(\mathrm{t}, 1 \mathrm{H}_{\text {para }}, \mathrm{Ph}, \mathrm{J}=6.8 \mathrm{~Hz}\right) ; 7.43\left(\mathrm{t}, 2 \mathrm{H}_{\text {meta }}, \mathrm{Ph}, \mathrm{J}=\right.$ $6.7 \mathrm{~Hz}) ; 7.91\left(\mathrm{~d}, 2 \mathrm{H}_{\text {ortho }}, \mathrm{Ph}, \mathrm{J}=5.3 \mathrm{~Hz}\right) ; 7.21\left(\mathrm{t}, 1 \mathrm{H}_{\text {para }}\right.$, $\mathrm{NHPh}, \mathrm{J}=6.2 \mathrm{~Hz}$ ); 7.37 (t, 2H meta $\mathrm{NHPh}, \mathrm{J}=6.4 \mathrm{~Hz}) ; 7.58$ (d, $2 \mathrm{H}_{\text {ortho }}$ NHPh, J = 5.6 Hz); 8.17 (s, 1H, HC=N); 10.11 (s, 1H, NHPh); 11.83 (s, 1H, =N-NH). ${ }^{13} \mathrm{C}-\mathrm{NMR}$ (DMSO-d 6 ): $\delta$ 127.6, 128.6, 130.0, 134.0 (Ph); 125.3, 125.9, 128.0, 139.1 (NH-Ph); $142.9(\mathrm{HC}=\mathrm{N}) ; 176.0(\mathrm{C}=\mathrm{S})$.

\subsection{Synthesis of the palladium(II) and platinum(II) complexes (see Scheme 2)}

A solution of $\mathrm{Pd}(\mathrm{acac})_{2}(0.30 \mathrm{~g}, 1.0 \mathrm{mmol})$ in $\mathrm{CH}_{2} \mathrm{Cl}_{2} /$ $\mathrm{CH}_{3} \mathrm{OH}(30 \mathrm{~mL}, 2: 1 \mathrm{v} / \mathrm{v})$ or a solution of $\left(\mathrm{NH}_{4}\right)_{2} \mathrm{PtCl}_{4}$ $(0.1865 \mathrm{~g}, 0.5 \mathrm{mmol})$ in water/ethanol $(2: 1,15 \mathrm{~mL})$ was added dropwise to a stirred solution of the corresponding thiosemicarbazone $(2.0 \mathrm{mmol})$ in $60 \mathrm{~mL}$ of methanol. Sodium acetate $(0.16 \mathrm{~g}, 2 \mathrm{mmol})$ in $3 \mathrm{~mL}$ of water was then added. The solution was refluxed for 2 hours and stirred for 24 hours at room temperature. The precipitate was collected by filtration and dried in vacuo.

\subsubsection{Palladium(II) complex of benzaldehyde thiosemicarbazone, $\operatorname{Pd}\left(L^{1}\right)_{2}$}

Yellow solid. Yield 70\%, m.p. 204-205 ${ }^{\circ}$ C. Anal. Calc. For $\mathrm{C}_{16} \mathrm{H}_{16} \mathrm{~N}_{6} \mathrm{~S}_{2} \mathrm{Pd}(462.9 \mathrm{~g} / \mathrm{mol})$ : C, 41.5\%; H, 3.5\%; N, 18.2\%; S, $13.9 \%$. Found: C, 40.9\%; H, 3.6\%; N, 18.6\%; S, $13.5 \%$. FAB(+)-MS: m/z $463\left(\mathrm{M}^{+}, 60 \%\right)$; IR $\left(\mathrm{KBr}, \mathrm{cm}^{-1}\right): v\left(\mathrm{NH}_{2}\right)$ 3390, 3367; $v(\mathrm{C}=\mathrm{N})$ 1582; $v(\mathrm{C}=\mathrm{S})$ 805. ${ }^{1} \mathrm{H}-\mathrm{NMR}$ (DMSO$\left.\mathrm{d}_{6}\right): \delta 7.49,7.45,7.41,7.39(\mathrm{~m}, \mathrm{Ph}) ; 8.13(\mathrm{~s}, 2 \mathrm{H}, \mathrm{HC}=\mathrm{N})$; $8.29,8.21\left(\mathrm{~d}, 4 \mathrm{H}, \mathrm{NH}_{2}\right)$. 


\subsubsection{Palladium(II) complex of m-cyanobenzaldehyde thiosemicarbazone, $\operatorname{Pd}\left(L^{2}\right)_{2}$}

Crystals suitable for X-ray structure determination were obtained by slowly evaporating a methanol/dichloromethane (2:1) solution at room temperature.

Orange crystals. Yield $63 \%$, m.p. $>240^{\circ} \mathrm{C}$ (decomp.). Anal. Calc. for $\mathrm{C}_{18} \mathrm{H}_{14} \mathrm{~N}_{8} \mathrm{~S}_{2} \mathrm{Pd} \cdot \mathrm{H}_{2} \mathrm{O}(530.9 \mathrm{~g} / \mathrm{mol})$ : C, $40.7 \%$; H, 3.0\%; N, 21.1\%; S, 12.1\%; Found: C, $42.0 \%$; H, 2.7\%; N, 21.6\%; S, 12.3\%. FAB(+)-MS: m/z $513\left(\mathrm{M}^{+}-\mathrm{H}_{2} \mathrm{O}, 100 \%\right)$; IR $\left(\mathrm{KBr}, \mathrm{cm}^{-1}\right): v\left(\mathrm{NH}_{2}\right) 3405,3377 ; \nu(\mathrm{CN}) 2230 ; \nu(\mathrm{C}=\mathrm{N})$ $1570 ; \nu(\mathrm{C}=\mathrm{S}) 815 .{ }^{1} \mathrm{H}-\mathrm{NMR}\left(\mathrm{DMSO}-\mathrm{d}_{6}\right): \delta 7.75,7.65,7.55$ (m, $\mathrm{Ph}) ; 8.06(\mathrm{~s}, 2 \mathrm{H}, \mathrm{HC}=\mathrm{N}) ; 8.68\left(\mathrm{~s}, 2 \mathrm{H}, \mathrm{NH}_{2}\right)$.

\subsubsection{Palladium(II) complex of o-nitrobenzaldehyde thiosemicarbazone, $\operatorname{Pd}\left(L^{3}\right)_{2}$}

Yellow solid. Yield 61\%, m.p. $>260^{\circ} \mathrm{C}$ (decomp.). Anal. Calc. for $\mathrm{C}_{16} \mathrm{H}_{14} \mathrm{O}_{4} \mathrm{~N}_{8} \mathrm{~S}_{2} \mathrm{Pd}(552.9 \mathrm{~g} / \mathrm{mol})$ : C, $34.8 \% ; \mathrm{H}, 2.6 \% ; \mathrm{N}$, $20.3 \%$; S, 11.6\%. Found: C, 34.6\%; H, 2.5\%; N, 20.6\%; S, 11.3\%. $\mathrm{FAB}(+)-\mathrm{MS}: \mathrm{m} / \mathrm{z} 553\left(\mathrm{M}^{+}, 74 \%\right)$; IR $\left(\mathrm{KBr}, \mathrm{cm}^{-1}\right)$ : $\nu\left(\mathrm{NH}_{2}\right) 3400,3350 ; \nu(\mathrm{C}=\mathrm{N}) 1585 ; \nu(\mathrm{C}=\mathrm{S}) 820 .{ }^{1} \mathrm{H}-\mathrm{NMR}$ $\left(\right.$ DMSO- $\left.\mathrm{d}_{6}\right): \delta 7.85,7.80,7.70(\mathrm{~m}, \mathrm{Ph}) ; 8.15(\mathrm{~d}, 2 \mathrm{H}, \mathrm{HC}=\mathrm{N})$; $8.44\left(\mathrm{~s}, 2 \mathrm{H}, \mathrm{NH}_{2}\right)$.

\subsubsection{Platinum(II) tetranuclear complex, $\mathrm{Pt}_{4}\left(L^{4}\right)_{4}$}

Crystals suitable for structure determination by X-ray diffraction were obtained by slowly evaporating an ethanol/chloroform (2:1) solution at room temperature.

Red crystals. Yield $57 \%$, m.p. $188-189^{\circ} \mathrm{C}$. Anal. Calc. For $\mathrm{C}_{56} \mathrm{H}_{44} \mathrm{~N}_{12} \mathrm{~S}_{4} \mathrm{Pt}_{4} \cdot 2 \mathrm{C}_{2} \mathrm{H}_{5} \mathrm{OH}(1885.8 \mathrm{~g} / \mathrm{mol})$ : C, $38.2 \%$; H, 3.0\%; N, 8.9\%; S, 6.8\%. Found: C, 38.0\%; H, 3.0\%; N, $8.6 \%$; S, 6.5\%; IR $\left(\mathrm{KBr}, \mathrm{cm}^{-1}\right): \nu(\mathrm{NHPh}) 3200 ; \nu(\mathrm{C}=\mathrm{N}) 1590$; $\nu(\mathrm{C}=\mathrm{S}) \quad 840 .{ }^{1} \mathrm{H}-\mathrm{NMR}\left(\mathrm{DMSO}-\mathrm{d}_{6}\right): \delta 7.50-7.80(\mathrm{~m}, \mathrm{Ph})$; 7.0-7.4 (m, NHPh); $8.0(\mathrm{~d}, 4 \mathrm{H}, \mathrm{HC}=\mathrm{N}) ; 9.15,9.68(\mathrm{~d}, 4 \mathrm{H}$, $\mathrm{NHPh})$.

\subsection{Crystal structure determinations}

The data for the crystal structure determinations were collected on a Siemens CCD smart diffractometer ( $\mathrm{HL}^{4}$, $\left.\mathrm{Pt}_{4}\left(\mathrm{~L}^{4}\right)_{4}\right)$ and a Stoe IPDS2 diffractometer $\left(\mathrm{Pd}\left(\mathrm{L}^{2}\right)_{2}\right)(\mathrm{MoK} \alpha$ radiation, $\lambda=0.71073 \AA$, graphite monochromator). The intensities were corrected for Lorentz and polarization effects and for absorption using SADABS $\left(\mathrm{Pt}_{4}\left(\mathrm{~L}^{4}\right)_{4}\right)$ and X-RED/XSHAPE $\left(\operatorname{Pd}\left(\mathrm{L}^{2}\right)_{2}\right)$. The structures were solved by direct methods, which revealed the positions of all nonhydrogen atoms and refined on $F^{2}$ by a full matrix least-squares procedure using anisotropic displacement parameters with the exception of the solvent molecules in $\mathrm{Pt}_{4}\left(\mathrm{~L}^{4}\right)_{4}$ which were refined isotropically. The hydrogen atoms for $\mathrm{HL}^{4}$ and $\operatorname{Pd}\left(\mathrm{L}^{2}\right)_{2}$ were located from different Fourier syntheses and refined isotropically. For $\mathrm{Pt}_{4}\left(\mathrm{~L}^{4}\right)_{4}$, the hydrogen atoms were included in calculated positions and refined in riding mode. All calculations were carried out using the SHELXS-97 and SHELXL-97 programs $[21,22]$. Crystal data collection and refinement details for the ligand $\mathrm{HL}^{4}$, the palladium(II) complex $\mathrm{Pd}\left(\mathrm{L}^{2}\right)_{2}$, and the platinum(II) tetranuclear complex $\mathrm{Pt}_{4}\left(\mathrm{~L}^{4}\right)_{4}$ are summarized in Table 1 .

\subsection{Biological activity}

\subsubsection{Cell culture}

The antitumor assays were performed employing the following cell lines: H460 (human lung large cell carcinoma), ME180 (human cervix epidermoid carcinoma), M-14 (human amelanotic melanoma), DU145 (human prostate carcinoma), MCF-7 (human breast adenocarcinoma), HT-29 (human colon adenocarcinoma), PC3 (human prostate carcinoma), and K562 (human chronic myelogenous leukemia). Cells were maintained in Dulbecco's Modified Eagle's Medium (DMEM) supplemented with 10\% fetal calf serum and $50 \mu \mathrm{g} / \mathrm{mL}$ gentamycin, and grown at $37^{\circ} \mathrm{C}$ in a $5 \% \mathrm{CO}_{2}$ humidified environment.

\subsubsection{Assessment of cytotoxicity}

Cells were inoculated into 96-well tissue culture plates at a density of 3000-5000 cells per well and incubated at $37^{\circ} \mathrm{C}$ with their corresponding growth medium for 24 hours to allow cells to attach. A plate containing each of these cells was fixed in situ with trichloroacetic acid (TCA) in order to obtain the cell values at zero time before adding the test compounds. The rest of the plates containing the different cell lines received serial dilutions of the ligands and palladium(II) complexes in DMSO to be incubated at $37^{\circ} \mathrm{C}$ for 48 hours. The assay was terminated by the addition of cold TCA. The cell numbers in each well was determined using the sulforhodamine B (SRB) assay [23]. TCA-treated plates were incubated at $4^{\circ} \mathrm{C}$ for 1 hour and then the cells were washed five times with tap water and dried completely at room temperature. The cells were stained for 20 minutes with a solution of $0.4 \%$ sulforhodamine $\mathrm{B}$ in $1 \%$ acetic acid. At the end of the staining period, unbound dye was removed by washing four times with $1 \%$ acetic acid until the washing solution became colorless. After complete drying, bound dye was solubilized with $10 \mathrm{mM}$ Tris buffer ( $\mathrm{pH} 10.5)$ and the absorbance reads on an automated plate reader at a wavelength of $550 \mathrm{~nm}$. The $\mathrm{IC}_{50}$ value was defined as the concentration of test sample resulting in a $50 \%$ reduction of absorbance as compared with untreated controls that received a serial dilution of the solvent in which the test samples were dissolved, and was determined by linear regression analysis.

For K562 cells, which grow in suspension, instead of fixing and staining with SRB, cells were counted using a Coulter counter.

\section{RESULTS AND DISCUSSION}

\subsection{IR spectra of the ligands and their complexes}

The infrared absorption bands become very useful for determining the mode of coordination of the ligands to metal. In the IR spectra, the broad bands of the $-\mathrm{NH}$ group observed at $3236-3250 \mathrm{~cm}^{-1}$ for the ligands disappear in 
TABLE 1: Crystal data and refinement summary.

\begin{tabular}{|c|c|c|c|}
\hline & $\mathrm{HL}^{4}$ & $\mathrm{Pd}\left(\mathrm{L}^{2}\right)_{2} \cdot \mathrm{H}_{2} \mathrm{O}$ & $\mathrm{Pt}_{4}\left(\mathrm{~L}^{4}\right)_{4} \cdot 2 \mathrm{C}_{2} \mathrm{H}_{5} \mathrm{OH}$ \\
\hline Empirical formula & $\mathrm{C}_{14} \mathrm{H}_{13} \mathrm{~N}_{3} \mathrm{~S}$ & $\mathrm{C}_{18} \mathrm{H}_{16} \mathrm{~N}_{8} \mathrm{OPdS}_{2}$ & $\mathrm{C}_{60} \mathrm{H}_{56} \mathrm{~N}_{12} \mathrm{O}_{2} \mathrm{Pt}_{4} \mathrm{~S}_{4}$ \\
\hline Formula weight (g/mol) & 255.33 & 530.91 & 1885.77 \\
\hline Crystal habit, color & Yellow plates & Orange prisms & Red prisms \\
\hline Crystal system & Triclinic & Monoclinic & Monoclinic \\
\hline Space group & P-1 & $\mathrm{C} 2 / \mathrm{c}$ & $\mathrm{P} 2_{1}$ \\
\hline $\mathrm{a}(\AA)$ & $5.988(1)$ & $20.016(4)$ & $12.708(1)$ \\
\hline $\mathrm{b}(\AA)$ & $10.285(2)$ & $6.421(1)$ & $13.639(1)$ \\
\hline c $(\AA)$ & $11.410(2)$ & $18.511(4)$ & $17.031(1)$ \\
\hline$\alpha\left({ }^{\circ}\right)$ & $68.040(2)$ & & \\
\hline$\beta\left({ }^{\circ}\right)$ & $82.514(3)$ & $120.78(3)$ & $94.054(1)$ \\
\hline$\gamma\left({ }^{\circ}\right)$ & $86.886(2)$ & & \\
\hline Volume $\left(\AA^{3}\right)$ & $646.1(2)$ & $2044.0(7)$ & $2944.5(3)$ \\
\hline $\mathrm{Z} ; \mathrm{F}(000)$ & $2 ; 268$ & $4 ; 1064$ & $2 ; 1784$ \\
\hline Density $_{\text {calc }}\left(\mathrm{g} / \mathrm{cm}^{3}\right)$ & 1.313 & 1.725 & 2.127 \\
\hline Crystal size (mm) & $0.44 \times 0.20 \times 0.04$ & $0.43 \times 0.39 \times 0.07$ & $0.16 \times 0.16 \times 0.05$ \\
\hline$\mu\left(\mathrm{MoK}_{\alpha}\right)\left(\mathrm{mm}^{-1}\right)$ & 0.235 & 1.141 & 9.669 \\
\hline $2 \theta$ range $\left(^{\circ}\right)$ & $3.8-50.0$ & $6.8-56.2$ & $3.8-59.0$ \\
\hline Temperature (K) & 220 & 213 & 213 \\
\hline Measured reflections & 3388 & 9478 & 19123 \\
\hline$R_{\text {int }}$ & 0.0290 & 0.0635 & 0.0224 \\
\hline Unique reflections & 2252 & 2462 & 13693 \\
\hline Observed reflections $(I>2 \sigma(I))$ & 1939 & 2012 & 12253 \\
\hline Refined parameters & 215 & 170 & 713 \\
\hline$w R_{2}$ (unique reflections) & 0.1693 & 0.0929 & 0.0774 \\
\hline$R_{1}$ (observed reflections) & 0.0618 & 0.0331 & 0.0338 \\
\hline Largest difference peak and hole $\left(\mathrm{e} / \AA^{3}\right)$ & $0.38 /-0.31$ & $1.26 /-0.88$ & $1.71 /-1.14$ \\
\hline
\end{tabular}

the complexes spectra, which indicates the deprotonation of the NH-CS group. The strong bands observed at 1596$1625 \mathrm{~cm}^{-1}$ range in the free ligands have been assigned to $v(\mathrm{C}=\mathrm{N})$ stretching vibrations [24]. On complexation, these bands were observed to be shifted to lower frequencies $\left(1570-1590 \mathrm{~cm}^{-1}\right)$, which are in agreement with the wave numbers for other bis-chelate complexes [6, 25, 26]. These results indicate that the imine nitrogen is coordinated to the metal ion. All ligands showed medium bands in the $880-915 \mathrm{~cm}^{-1}$ range ascribed to $\nu(\mathrm{C}=\mathrm{S})$ vibrations. These absorption bands shift $65-80 \mathrm{~cm}^{-1}$ to lower frequencies on the coordination of the thiocarbonyl sulfur to palladium(II) or platinum(II) ion. These results are in agreement with other thiosemicarbazone complexes [24, 27]. In addition, the vibrational frequencies of the $-\mathrm{NH}_{2}$ groups remain unchanged for both the ligands and the complexes. This evidence indicates the noncoordination of the $-\mathrm{NH}_{2}$ group to the $\mathrm{Pd}(\mathrm{II})$ center.

\subsection{NMR spectra of the ligands and their complexes}

In the ${ }^{1} \mathrm{H}-\mathrm{NMR}$ spectra of the ligands, the signals of the $=\mathrm{N}-\mathrm{NH}$ protons were observed as singlets at $\delta 11.42-11.83$. These signals disappeared in the ${ }^{1} \mathrm{H}$-NMR spectra of the palladium(II) and platinum(II) complexes indicating the deprotonation of the $=\mathrm{N}-\mathrm{NH}$ group. The signals of the $\mathrm{HC}=\mathrm{N}$ protons which appear as singlets at $\delta 8.03-8.17$ in the ligands show a shift to downfield in $\delta 0.03-0.80$ after complexation. This shift indicates the coordination of the imine nitrogen to the metal center [28]. The signals of the aromatic protons of the ligands appeared at $\delta 7.21-$ 7.91, and the resonance lines found correspond to the calculated multiplicity. These signals do not suffer relevant changes in the chemical shifts for the palladium(II) and platinum(II) complexes. The $\mathrm{NH}_{2}$ signal in the ligands $\mathrm{HL}^{1}$, $\mathrm{HL}^{2}$, and $\mathrm{HL}^{3}$ appears as doublets at $\delta 7.98-8.45$ due to the nonequivalence of the amine protons. This evidence is attributed to the restricted rotation around $\mathrm{C}-\mathrm{N}$ bond (thiocarbonyl carbon and terminal amine nitrogen) due to its partial double bond character $[14,29]$. The presence of the phenyl group on the terminal amine (NHPh) of the ligand $\mathrm{HL}^{4}$ produces a downfield chemical shift at $\delta 2.1$ with respect to the $\mathrm{NH}_{2}$ group of the ligand $\mathrm{HL}^{1}$. This reveals that $\mathrm{HL}^{4}$ is slightly less basic than $\mathrm{HL}^{1}$. The resonance signals of the $-\mathrm{NH}_{2}$ or $\mathrm{NHPh}$ groups in the palladium(II) and platinum(II) complexes do not change, and this evidence indicates that the amine groups are not coordinated to the metal ion [14].

In the ${ }^{13} \mathrm{C}-\mathrm{NMR}$ spectra, the carbon resonance signals of the $\mathrm{HC}=\mathrm{N}$ group appeared at $\delta$ 139.66-148.3. The 


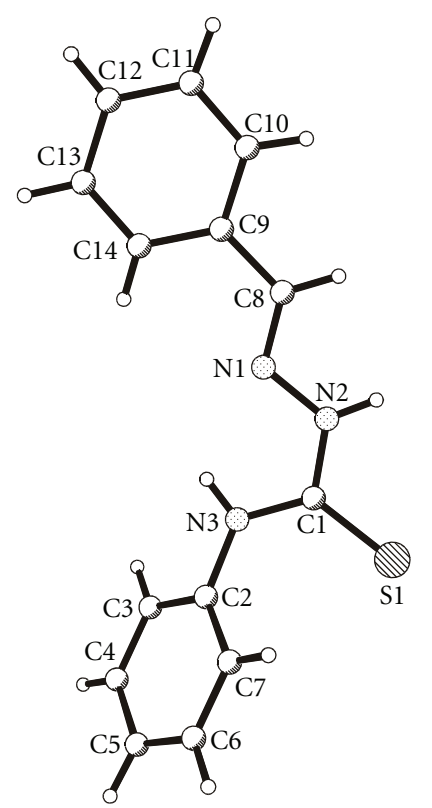

FIGURE 1: Molecular structure of $\mathrm{HL}^{4}$.

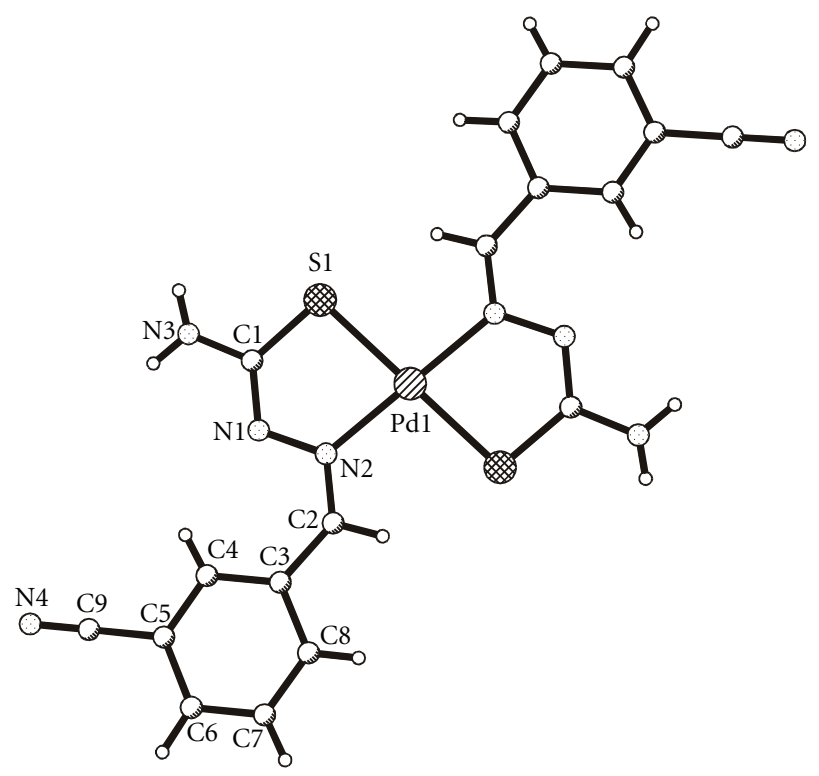

Figure 2: Molecular structure of $\mathrm{Pd}\left(\mathrm{L}^{2}\right)_{2}$.

results are similar to the chemical shifts found for the ligands benzophenone thiosemicarbazide and phenylpropenal thiosemicarbazone (both found at $\delta 141$ ) $[30,31]$. The $\mathrm{C}=\mathrm{S}$ signals observed at $\delta$ 178.5-176.0 are characteristic for this group, while the aromatic carbons were observed at $\delta 139.1-$ 124.5 .

\subsection{Structural data}

The molecular structures of $\mathrm{HL}^{4}, \mathrm{Pd}\left(\mathrm{L}^{2}\right)_{2}$, and $\mathrm{Pt}_{4}\left(\mathrm{~L}^{4}\right)_{4}$ are shown in Figures 1, 2, and 3, respectively, whereas their selected bond lengths and bond angles are presented in Tables 2 and 3.
TABLe 2: Selected bond lengths $(\AA)$ for the $\mathrm{HL}^{4}$ ligand and the $\mathrm{Pd}\left(\mathrm{L}^{2}\right)_{2}$ and $\mathrm{Pt}_{4}\left(\mathrm{~L}^{4}\right)_{4}$ complexes.

\begin{tabular}{lccc}
\hline & $\mathrm{HL}^{4}$ & $\left.\mathrm{Pd}^{2} \mathrm{~L}^{2}\right)_{2}$ & $\mathrm{Pt}_{4}\left(\mathrm{~L}^{4}\right)_{4}$ \\
\hline S1-C1 & $1.686(3)$ & $1.746(2)$ & $1.812(9)$ \\
N1-N2 & $1.378(4)$ & $1.378(2)$ & $1.389(10)$ \\
N1-C8 & $1.284(4)$ & & $1.293(11)$ \\
N2-C1 & $1.354(4)$ & & $1.296(11)$ \\
N3-C1 & $1.342(4)$ & $1.348(3)$ & $1.354(11)$ \\
N3-C2 & $1.422(4)$ & & $1.427(12)$ \\
C2-C3 & & $1.472(3)$ & \\
C8-C9 & $1.457(4)$ & & $1.441(13)$ \\
N1-C1 & & $1.316(3)$ & \\
N2-C2 & & $1.306(3)$ & \\
Pd1-S1 & & $2.297(1)$ & \\
Pd1-N2 & & $2.049(2)$ & \\
Pt-S (intraligand) & & & $2.351(2)$ \\
Pt-S' (bridging) & & & $2.298(2)$ \\
Pt-N1 & & & $1.991(7)$ \\
Pt-C10 & & & $2.015(8)$ \\
\hline
\end{tabular}

TABLE 3: Selected bond angles $\left(^{\circ}\right)$ for the $\mathrm{HL}^{4}$ ligand and the $\mathrm{Pd}\left(\mathrm{L}^{2}\right)_{2}$ and $\mathrm{Pt}_{4}\left(\mathrm{~L}^{4}\right)_{4}$ complexes.

\begin{tabular}{lccc}
\hline & $\mathrm{HL}^{4}$ & $\left.\mathrm{Pd}^{2}\right)_{2}$ & $\mathrm{Pt}_{4}\left(\mathrm{~L}^{4}\right)_{4}$ \\
\hline N2-N1-C8 & $115.0(3)$ & & $118.5(7)$ \\
N1-N2-C1 & $119.8(3)$ & & $113.4(7)$ \\
C1-N3-C2 & $127.7(3)$ & & $127.6(8)$ \\
S1-C1-N2 & $118.7(2)$ & & $124.8(7)$ \\
S1-C1-N3 & $126.1(2)$ & $117.4(2)$ & $114.4(7)$ \\
N2-C1-N3 & $115.2(3)$ & & $120.7(8)$ \\
N1-C8-C9 & $121.8(3)$ & & $115.0(8)$ \\
N2-N1-C1 & & $113.5(2)$ & \\
N1-N2-C2 & & $116.5(2)$ & \\
S1-C1-N1 & & $125.3(2)$ & \\
N1-C1-N3 & & $117.3(2)$ & \\
N2-C2-C3 & & $131.6(2)$ & \\
S1-Pd1-N2 & & $82.8(1)$ & \\
S-Pt-N1 & & & $83.1(2)$ \\
N1-Pt-C10 & & & $80.9(3)$ \\
C10-Pt-S' & & & $94.8(3)$ \\
S-Pt-S' & & & $101.5(1)$ \\
Pt-S1-S1 & & & $93.6(3)$ \\
Pt-N1-N2 & & & $117.2(6)$ \\
Pt-N1-C8 & & & \\
\hline
\end{tabular}

\subsubsection{4-phenyl-1-benzaldehyde thiosemicarbazone $\mathrm{HL}^{4}$}

The reaction product of benzaldehyde and 4-phenyl thiosemicarbazide shows the expected bond lengths, especially the N1-C8 double bond with a length of 1.284(4) $\AA$ (see Figure 1). The molecular fragment N3-C1(S1)-N2-N1C8 is nearly planar. The C9-C14 phenyl ring deviates only slightly from this mean plane and forms an angle of $56.4(1)^{\circ}$ with the C2-C7 phenyl ring. 
There are two hydrogen bonds: an intramolecular N3$\mathrm{H} \cdots \mathrm{N} 1[\mathrm{~N} 3-\mathrm{H} \quad 0.85 \AA, \mathrm{H} \cdots \mathrm{N} 1 \quad 2.17 \AA, \mathrm{N} 3 \cdots \mathrm{N} 1$ $\left.2.615 \AA, \mathrm{N} 3-\mathrm{H} \cdots \mathrm{N} 1112^{\circ}\right]$ hydrogen bond and an intermolecular N2-H . . S 1 [N2-H $0.88 \AA, \mathrm{H}$. . S $12.62 \AA$, N2 . . S $13.466 \AA$, N2-H . . S1 $162^{\circ}$ ] hydrogen bond. The latter leads to the formation of pairs of molecules in the crystal structure.

\subsubsection{Bis(3-cyanophenyl-1-benzaldehyde thiosemicarbazonato)palladium(II) $P d\left(L^{2}\right)_{2}$}

3-cyanophenyl-1-benzaldehyde thiosemicarbazone reacts with palladium(II) acetylacetonate to form a bis-chelate with $\mathrm{C}_{\mathrm{i}}$ molecular symmetry (see Figure 2). The deprotonated ligand coordinates bidentately through $\mathrm{S}$ and $\mathrm{N}$. The coordination of the $\mathrm{Pd}$ atom is square planar with a transarrangement of the coordinating atoms. It leads to a lengthening of the $\mathrm{S} 1-\mathrm{C} 1$ bond and a shortening of the N1-C1 bond. The Pd1S1N1N2C1 chelate ring is nearly planar and forms an angle of $11.5(1)^{\circ}$ with the C3-C8 phenyl ring.

In the crystal structure, one molecule of water per formula unit of the chelate is included.

There are three hydrogen bonds comprising the atom $\mathrm{O} 1$ of the water molecule and the atom $\mathrm{N} 4$ of the cyano group:

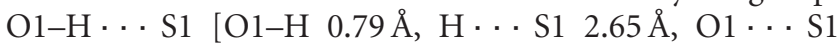
$3.418 \AA$, O1-H $\cdots$ S1 $166^{\circ}$ ], N3-H . . O1 [N3-H $0.87 \AA$, $\mathrm{H} \cdots \mathrm{O} 1 \quad 2.21 \AA, \quad \mathrm{N} 3 \cdots \mathrm{O} 1 \quad 3.081 \AA, \quad \mathrm{N} 3-\mathrm{H} \cdots \mathrm{O} 1$ $\left.173^{\circ}\right]$ and $\mathrm{N} 3-\mathrm{H}^{\prime} \ldots \mathrm{N} 4 \quad\left[\mathrm{~N} 3-\mathrm{H}^{\prime} \quad 0.85 \AA\right.$, $\mathrm{H}^{\prime} \ldots \mathrm{N} 4$ $2.22 \AA, \mathrm{N} 3 \cdots \mathrm{N} 43.054 \AA, \mathrm{N} 3-\mathrm{H}^{\prime} \cdots \mathrm{N} 4167^{\circ}$ ].

\subsubsection{Tetrakis (4-phenyl-1-benzaldehyde thiosemicarbazonato)tetraplatinum(II) $\mathrm{Pt}_{4}\left(L^{4}\right)_{4}$}

4-phenyl-1-benzaldehyde thiosemicarbazone reacts with ammonium tetrachloroplatinate(II) to form a tetranuclear complex with slightly distorted square planar geometry (see Figure 3). The tridentate ligands are deprotonated at the $\mathrm{NH}$ group and coordinated through $\mathrm{S}, \mathrm{N}$, and $\mathrm{C}$ (aromatic ring). The fourth coordination site at each $\mathrm{Pt}$ atom is occupied by a sulfur atom of a neighboring ligand. In this way, a puckered eight-membered ring of alternating $\mathrm{Pt}$ and $\mathrm{S}$ atoms is formed as the core of the molecule. Each of the four Pt atoms belongs to two fused five-membered chelate rings: the C, $\mathrm{N}$ metallocycle and the N, S chelate moiety.

The Pt-Pt distances range from $3.43 \AA$ to $3.84 \AA$. The Pt$S$ bonds form two distinct groups with significantly differing lengths: Pt-S chelating 2.351(2) $\AA$ and Pt-S bridging 2.298(2) $\AA$ (mean values). The coordination of the ligand to the $\mathrm{Pt}$ atoms leads to a lengthening of the $\mathrm{S}-\mathrm{C} 1$ bond (increased single-bond character) and a shortening of the neighboring N2-C1 bond (increased double-bond character) compared with the free ligand.

In the crystal structure, two molecules of ethanol per formula unit of the tetranuclear complex are included, which stabilize the crystal structure by hydrogen bonds. The $\mathrm{O} 1$ and $\mathrm{O} 2$ atoms of the ethanol molecules are bonded by hydrogen bonds to N3 atoms: N3-H . . O1 [N3-H $0.86 \AA$, H . . O1

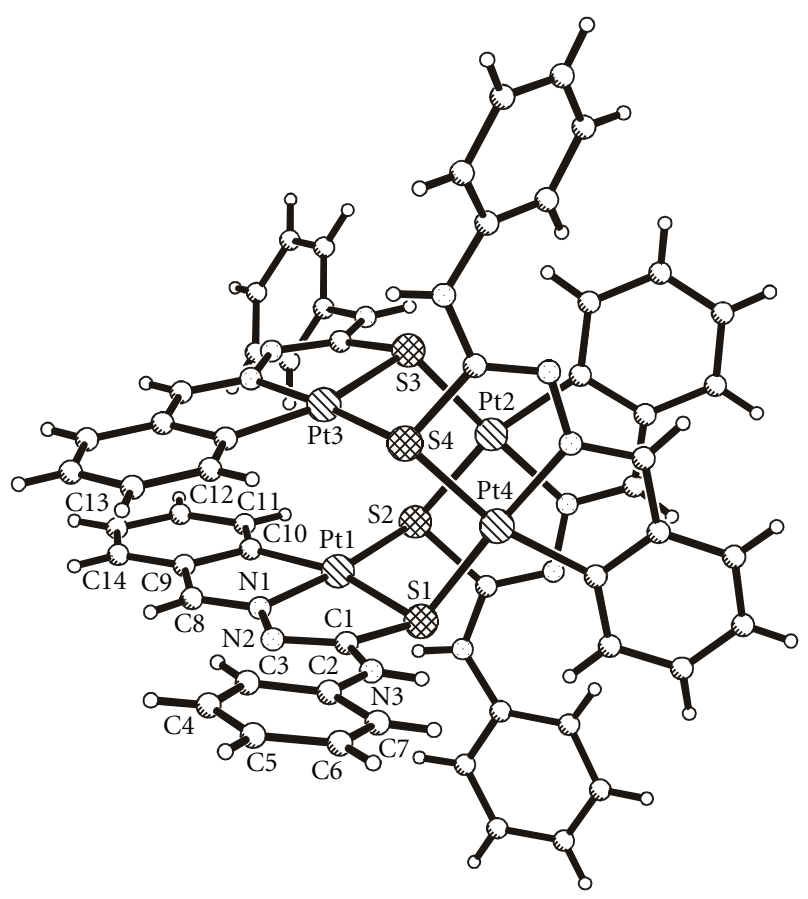

Figure 3: Molecular structure of $\mathrm{Pt}_{4}\left(\mathrm{~L}^{4}\right)_{4}$.

$2.07 \AA, \mathrm{N} 3 \cdots \mathrm{O} 12.898 \AA, \mathrm{N} 3-\mathrm{H} \cdots \mathrm{O} 11^{\circ} \mathrm{c} 2^{\circ}$ and N3$\mathrm{H}^{\prime} \ldots \mathrm{O} 2\left[\mathrm{~N} 3-\mathrm{H}^{\prime} \quad 0.86 \AA \mathrm{H}^{\prime} \ldots \mathrm{O} 22.14 \AA \AA\right.$, N3 … O 2 $\left.2.999 \AA, \mathrm{N} 3-\mathrm{H}^{\prime} \ldots \mathrm{O} 2173^{\circ}\right]$.

The formation of tetranuclear compounds was previously observed for Pd complexes with similar thiosemicarbazone ligands [14].

\subsection{Antitumor evaluation}

All ligands had a 50\% inhibitory concentration $\left(\mathrm{IC}_{50}\right)>$ $40 \mu \mathrm{M}$ against the used human tumor cell lines. As shown in Table 4, the palladium(II) and platinum(II) complexes were more cytotoxic $\left(\mathrm{IC}_{50}=0.08-12.46 \mu \mathrm{M}\right)$ than their respective ligands. These results reveal that the cytotoxic activity increases dramatically when ligands are coordinated to the metal ion $[18,19,32]$.

The $\mathrm{Pd}\left(\mathrm{L}^{2}\right)_{2}$ complex with a cyano group in the meta position of the aromatic ring and the $\mathrm{Pt}_{4}\left(\mathrm{~L}^{4}\right)_{4}$ tetranuclear complex with the phenyl group in the terminal amine of the ligand showed to be more cytotoxic $\left(\mathrm{IC}_{50}=0.45-3.67\right.$ and $0.07-0.12 \mu \mathrm{M}$, resp.) than the other $\mathrm{Pd}\left(\mathrm{L}^{1}\right)_{2}$ and $\mathrm{Pd}\left(\mathrm{L}^{3}\right)_{2}$ complexes against all tested human tumor cell lines. These results indicate that the cytotoxic activity is enhanced when four ligands are coordinated to four platinum atoms.

Probably, the high cytotoxicity of the $\mathrm{Pd}\left(\mathrm{L}^{2}\right)_{2}$ and $\mathrm{Pt}_{4}\left(\mathrm{~L}^{4}\right)_{4}$ complexes may be related to the intercalation of each metal complex between nitrogen bases of the DNA tumor cells, causing greater conformational changes in the double helix of DNA and then producing cell death $[33,34]$.

On the other hand, the $\mathrm{Pt}_{4}\left(\mathrm{~L}^{4}\right)_{4}$ tetranuclear complex was more cytotoxic $\left(\mathrm{IC}_{50}=0.08 \mu \mathrm{M}\right)$ compared with the cytotoxic activity shown by cisplatin $\left(\mathrm{IC}_{50}=7.0 \mu \mathrm{M}\right)$ assayed in (HL60) human leukemia cells [12]. With respect to 
TABLE 4: $\mathrm{IC}_{50}(\mu \mathrm{M})$ values of the palladium complexes, $\mathrm{Pd}\left({ }^{1-3}\right)_{2}$, and the platinum tetranuclear complex, $\mathrm{Pt}_{4}\left(\mathrm{~L}^{4}\right)_{4}$, against the different human tumor cell lines.

\begin{tabular}{|c|c|c|c|c|}
\hline Human tumor cell lines & $\operatorname{Pd}\left(\mathrm{L}^{1}\right)_{2}$ & $\mathrm{Pd}\left(\mathrm{L}^{2}\right)_{2}$ & $\operatorname{Pd}\left(\mathrm{L}^{3}\right)_{2}$ & $\mathrm{Pt}_{4}\left(\mathrm{~L}^{4}\right)_{4}$ \\
\hline Lung large cell carcinoma $(\mathrm{H} 460)$ & 8.73 & 3.53 & 5.82 & 0.09 \\
\hline Cervix epidermoid carcinoma (ME180) & 10.47 & 3.67 & 8.06 & 0.12 \\
\hline Prostate carcinoma (DU145) & 11.59 & 1.99 & 9.30 & 0.10 \\
\hline Breast adenocarcinoma (MCF-7) & 8.18 & 2.09 & 6.14 & 0.08 \\
\hline Amelanotic melanoma (M-14) & 12.46 & 1.87 & 8.74 & 0.11 \\
\hline Colon adenocarcinoma (HT-29) & 7.45 & 1.35 & 5.96 & 0.07 \\
\hline Prostate carcinoma (PC-3) & 10.20 & 1.56 & 7.36 & 0.08 \\
\hline Chronic myelogenous leukemia (K562) & 6.15 & 0.45 & 3.04 & 0.08 \\
\hline
\end{tabular}

${ }^{(a)} \mathrm{Cl}_{50}$ corresponds to the concentration required to inhibit a 50\% of the cell growth when the cells are exposed to the compounds during 48 hours. Each value is the average of two independent experiments.

the cytotoxicity shown by the square planar copper(II) complexes with carboxamidrazone ligands $\left(\mathrm{IC}_{50}=3.0 \mu \mathrm{M}\right)$, assayed in vitro against to the (MCF-7) human breast adenocarcinoma cell line [35], the $\mathrm{Pt}_{4}\left(\mathrm{~L}^{4}\right)_{4}$ complex resulted to be more cytotoxic, while the $\mathrm{Pd}\left(\mathrm{L}^{2}\right)_{2}$ complex showed a similar inhibition concentration $\left(\mathrm{IC}_{50}=2.09 \mu \mathrm{M}\right)$. In relation to other palladium(II) and platinum(II) complexes of the $\mathrm{M}(\mathrm{HL}) \mathrm{Cl}_{2}$ type with phenyl acetaldehyde thiosemicarbazone ligands $\left(\mathrm{IC}_{50}=38\right.$ and $9 \mu \mathrm{M}$, resp. $)$ assayed in the K562 human chronic myelogenous leukemia cell line [12], the $\mathrm{Pd}\left(\mathrm{L}^{2}\right)_{2}$ and $\mathrm{Pt}_{4}\left(\mathrm{~L}^{4}\right)_{4}$ complexes showed higher cytotoxic activity. In addition, the $\mathrm{Pd}\left(\mathrm{L}^{2}\right)_{2}$ complex resulted to be more cytotoxic $\left(\mathrm{IC}_{50}=2.09 \mu \mathrm{M}\right)$ than the palladium(II) and copper(II) complexes of the $\mathrm{M}(\mathrm{L}) \mathrm{Cl}$ type $\left(\mathrm{IC}_{50}=12.94\right.$ and 3.98 , resp.) and the $\mathrm{NiL}_{2}$ complex $\left(\mathrm{IC}_{50}=2.25 \mu \mathrm{M}\right)$ with 1,2-naphthoquinone-1-thiosemicarbazone ligands, tested in vitro against to the MCF-7 human breast adenocarcinoma cell line [34].

In summary, we have prepared the palladium(II) bischelate complexes and the platinum(II) tetranuclear complex, $\mathrm{Pd}\left(\mathrm{L}^{1-3}\right)_{2}$, and $\mathrm{Pt}_{4}\left(\mathrm{~L}^{4}\right)_{4}$, which were more cytotoxic on all the human tumor cell lines at low micromolar concentrations with respect to the free ligands. The crystal structure of $\mathrm{Pd}\left(\mathrm{L}^{2}\right)_{2}$ shows that the palladium atom has a square-planar geometry with two bidentate ligands having sulfur and nitrogen as donor atoms in trans positions. The complex $\mathrm{Pt}_{4}\left(\mathrm{~L}^{4}\right)_{4}$ has a tetranuclear structure with four tridentate $(\mathrm{C}, \mathrm{N}, \mathrm{S})$ ligands coordinated to four platinum atoms.

\section{Supplementary material}

Further details of the crystal structure determination are available on request from the Cambridge Crystallographic Data Center (CCDC, 12 Union Road, Cambidge CB2 1EZ, UK; fax: +44 1223 336033; email: deposit@ccdc.cam.ac.uk), on quoting the depositing numbers CCDC 694972 for $\mathrm{HL}^{4}$, 694973 for $\mathrm{Pd}\left(\mathrm{L}^{2}\right)_{2}$, and 694974 for $\mathrm{Pt}_{4}\left(\mathrm{~L}^{4}\right)_{4}$, the names of the authors, and the journal citation.

\section{ACKNOWLEDGMENTS}

Wilfredo Hernández thanks Universidad de Lima Research Institute for financial support to carry out the research work. The authors also thank the Research Laboratory of the Faculty of Sciences and Philosophy, Universidad Peruana Cayetano Heredia for the biological studies of the compounds. Evgenia Spodine thanks FONDAP 11980002 grant for financial support.

\section{REFERENCES}

[1] D. Kovala-Demertzi, A. Boccarelli, M. A. Demertzis, and M. Coluccia, "In vitro antitumor activity of 2-acetyl pyridine $4 \mathrm{~N}$-ethyl thiosemicarbazone and its platinum(II) and palladium(II) complexes," Chemotherapy, vol. 53, no. 2, pp. 148$152,2007$.

[2] D. Kovala-Demertzi, T. Varadinova, P. Genova, P. Souza, and M. A. Demertzis, "Platinum(II) and palladium(II) complexes of pyridine-2-carbaldehyde thiosemicarbazone as alternative antiherpes simplex virus agents," Bioinorganic Chemistry and Applications, vol. 2007, Article ID 56165, 6 pages, 2007.

[3] J. P. Scovill, D. L. Klayman, and C. F. Franchino, "2acetylpyridine thiosemicarbazones. 4 . Complexes with transition metals as antimalarial and antileukemic agents," Journal of Medicinal Chemistry, vol. 25, no. 10, pp. 1261-1264, 1982.

[4] A. G. Quiroga, J. M. Pérez, I. López-Solera, et al., "Novel tetranuclear orthometalated complexes of $\mathrm{Pd}(\mathrm{II})$ and $\mathrm{Pt}(\mathrm{II})$ derived from $p$-isopropylbenzaldehyde thiosemicarbazone with cytotoxic activity in cis-DDP resistant tumor cell lines. Interaction of these complexes with DNA," Journal of Medicinal Chemistry, vol. 41, no. 9, pp. 1399-1408, 1998.

[5] R. F. F. Costa, A. P. Rebolledo, T. Matencio, et al., "Metal complexes of 2-benzoylpyridine-derived thiosemicarbazones: structural, electrochemical and biological studies," Journal of Coordination Chemistry, vol. 58, no. 15, pp. 1307-1319, 2005.

[6] R. K. Agarwal, L. Singh, and D. K. Sharma, "Synthesis, spectral, and biological properties of copper(II) complexes of thiosemicarbazones of Schiff bases derived from 4 -aminoantipyrine and aromatic aldehydes," Bioinorganic Chemistry and Applications, vol. 2006, Article ID 59509, 10 pages, 2006.

[7] O. P. Pandey, S. K. Sengupta, M. K. Mishra, and C. M. Tripathi, "Synthesis, spectral and antibacterial studies of binuclear titanium(IV) / zirconium(IV) complexes of piperazine dithiosemicarbazones," Bioinorganic Chemistry and Applications, vol. 1, no. 1, pp. 35-44, 2003.

[8] C. Shipman Jr., S. H. Smith, J. C. Drach, and D. L. Klayman, "Thiosemicarbazones of 2-acetylpyridine, 2-acetylquinoline, 1-acetylisoquinoline, and related compounds as inhibitors of 
herpes simplex virus in vitro and in a cutaneous herpes guinea pig model," Antiviral Research, vol. 6, no. 4, pp. 197-222, 1986.

[9] I. Pal, F. Basuli, and S. Bhattacharya, "Thiosemicarbazone complexes of the platinum metals. A story of variable coordination modes," Proceedings of the Indian Academy of Sciences: Chemical Sciences, vol. 114, no. 4, pp. 255-268, 2002.

[10] M. S. Bakkar, M. Yamin Siddiqi, and M. S. Monshi, "Preparation and investigation of the bonding mode in the complexes of Pt(II) with thiosemicarbazone ligands," Synthesis and Reactivity in Inorganic, Metal-Organic, and Nano-Metal Chemistry, vol. 33, no. 7, pp. 1157-1169, 2003.

[11] R. M. El-Shazly, G. A. A. Al-Hazmi, S. E. Ghazy, M. S. ElShahawi, and A. A. El-Asmy, "Synthesis and spectroscopic characterization of cobalt(II) thiosemicarbazone complexes," Journal of Coordination Chemistry, vol. 59, no. 8, pp. 845-859, 2006.

[12] H. Beraldo, "Semicarbazones and thiosemicarbazones: their wide pharmacological profile and clinical applications," Quimica Nova, vol. 27, no. 3, pp. 461-471, 2004.

[13] A. G. Quiroga, J. M. Pérez, I. López-Solera, et al., "Binuclear chloro-bridged palladated and platinated complexes derived from $p$-isopropylbenzaldehyde thiosemicarbazone with cytotoxicity against cisplatin resistant tumor cell lines," Journal of Inorganic Biochemistry, vol. 69, no. 4, pp. 275-281, 1998.

[14] J. M. Vila, Ma. T. Pereira, J. M. Ortigueira, et al., "Formation, characterization, and structural studies of novel thiosemicarbazone palladium(II) complexes. Crystal structures of $\left[\left\{\mathrm{Pd}\left[\mathrm{C}_{6} \mathrm{H}_{4} \mathrm{C}(\mathrm{ET})=\mathrm{NN}=\mathrm{C}(\mathrm{S}) \mathrm{NH}_{2}\right]\right\}_{4}\right],\left[\mathrm{Pd}\left\{\mathrm{C}_{6} \mathrm{H}_{4} \mathrm{C}(\mathrm{ET})=\right.\right.$ $\left.\left.\mathrm{NN}=\mathrm{C}(\mathrm{S}) \mathrm{NH}_{2}\right\}\left(\mathrm{PMePh}_{2}\right)\right]$ and $\left[\left\{\mathrm{Pd}\left[\mathrm{C}_{6} \mathrm{H}_{4} \mathrm{C}(\mathrm{ET})=\mathrm{NN}=\right.\right.\right.$ $\left.\left.\left.\mathrm{C}(\mathrm{S}) \mathrm{NH}_{2}\right]\right\}_{2}\left(\mu-\mathrm{Ph}_{2} \mathrm{PCH}_{2} \mathrm{PPh}_{2}\right)\right]$," Journal of the Chemical Society, Dalton Transactions, no. 23, pp. 4193-4201, 1999.

[15] J. V. Salyn, N. K. Zumadilov, V. I. Nefedov, et al., "ESCA Investigations on Heavy Metal Chelates of Substituted Nacyl-thio- and -selenoureas," Zeitschrift für Anorganische und Allgemeine Chemie, vol. 432, p. 275, 1977.

[16] R. Herzschuh, B. Birner, L. Beyer, F. Dietze, and E. Hoyer, "Mass Spectrometric Fragmentation of N-Benzoyl(thio)benzamides, $\mathrm{N}$-Benzoyl(thio, seleno)ureas, and their $\mathrm{Ni}(\mathrm{II})$ - and $\mathrm{Cu}(\mathrm{II})-1: 2$-chelates," Zeitschrift für Anorganische und Allgemeine Chemie, vol. 464, p. 159, 1980.

[17] W. Hernández, E. Spodine, K.-H. Hallmeier, R. Richter, U. Schröder, and L. Beyer, "Platinum(II) Mixed Ligand Complexes with Thiourea Derivatives, Dimethyl Sulphoxide and Chloride: Syntheses, Molecular Structures, and ESCA Data," Zeitschrift für Anorganische und Allgemeine Chemie, vol. 629, no. 14, p. 259, 2003.

[18] W. Hernández, E. Spodine, J. C. Muñoz, et al., "Synthesis, characterization and antitumor activity of cis-bis(acylthioureato) platinum(II) complexes, cis$\mathrm{PtL}_{2}\left[\mathrm{HL}^{1}=\mathrm{N}, \mathrm{N}\right.$-diphenyl- $N^{\prime}$-benzoylthiourea or $\mathrm{HL}^{2}=$ N,N-diphenyl- $N^{\prime}$-(p-nitrobenzoyl)thiourea]," Bioinorganic Chemistry and Applications, vol. 1, no. 3-4, pp. 271-284, 2003.

[19] W. Hernández, E. Spodine, L. Beyer, et al., "Synthesis, characterization and antitumor activity of copper(II) complexes, $\left[\mathrm{CuL}_{2}\right]\left[\mathrm{HL}^{1-3}=\mathrm{N}, \mathrm{N}\right.$-diethyl-N' ${ }^{\prime}$ (R-benzoyl)thiourea $(\mathrm{R}=\mathrm{H}$, o-Cl and $\left.\mathrm{p}-\mathrm{NO}_{2}\right)$ ]," Bioinorganic Chemistry and Applications, vol. 3, no. 3-4, pp. 299-316, 2005.

[20] T. S. Lobana, A. Sánchez, J. S. Casas, et al., "Symmetrisation, isomerism and structural studies on novel phenylmercury(II) thiosemicarbazonates: correlation of the energy barrier to rotation of the amino group with the bonding parameters of the thioamide group," Journal of the Chemical Society, Dalton Transactions, no. 22, pp. 4289-4300, 1997.
[21] G. M. Sheldrick, SHELXS 97, Program for Solving Crystal Structures, University of Göttingen, 1997.

[22] G. M. Sheldrick, SHELXL 97, Program for Structure Refinement, University of Göttingen, 1997.

[23] P. Skehan, R. Storeng, D. Scudiero, et al., "New colorimetric cytotoxicity assay for anticancer-drug screening," Journal of the National Cancer Institute, vol. 82, no. 13, pp. 1107-1112, 1990.

[24] A. H. Al-Kubaisi, "Copper(II), nickel(II) and palladium(II) complexes of 2-oximino-3-thiosemicarbazone-2,3-butanedione," Bulletin of the Korean Chemical Society, vol. 25, no. 1, pp. 37-41, 2004.

[25] I. C. Mendes, J. P. Moreira, N. L. Speziali, A. S. Mangrich, J. A. Takahashi, and H. Beraldo, "N(4)-tolyl-2-benzoylpyridine thiosemicarbazones and their copper(II) complexes with significant antifungal activity. Crystal structure of $N(4)$-paratolyl-2-benzoylpyridine thiosemicarbazone," Journal of the Brazilian Chemical Society, vol. 17, no. 8, pp. 1571-1577, 2006.

[26] I. G. Santos, A. Hagenbach, and U. Abram, "Stable gold(III) complexes with thiosemicarbazone derivatives," Dalton Transactions, no. 4, pp. 677-682, 2004.

[27] S. Chandra, G. Singh, V. P. Tyagi, and S. Raizada, "Synthesis, ESR, magnetic, and electronic spectral studies on manganese(II) complexes of semicarbazone and thiosemicarbazone," Synthesis and Reactivity in Inorganic, Metal-Organic, and Nano-Metal Chemistry, vol. 31, no. 10, pp. 1759-1769, 2001.

[28] H. S. Seleem, A. A. Emara, and M. Shebl, "The relationship between ligand structures and their $\mathrm{Co}^{\mathrm{II}}$ and $\mathrm{Ni}^{\mathrm{II}}$ complexes: synthesis and characterization of novel dimeric $\mathrm{Co}^{\mathrm{II}} / \mathrm{Co}^{\mathrm{III}}$ complexes of bis(thiosemicarbazone)," Journal of Coordination Chemistry, vol. 58, no. 12, pp. 1003-1019, 2005.

[29] T. S. Lobana, Rekha, B. S. Sidhu, A. Castineiras, E. Bermejo, and T. Nishioka, "Syntheses, NMR $\left({ }^{1} \mathrm{H},{ }^{31} \mathrm{P}\right)$ spectroscopy and crystal structures of complexes of copper(I) halides with isatin-3-thiosemicarbazones," Journal of Coordination Chemistry, vol. 58, no. 9, pp. 803-809, 2005.

[30] N. M. Samus', A. P. Gulya, V. I. Tsapkov, Yu. M. Chumakov, and T. Roshu, "Co-ordination compounds of cobalt, nickel, copper and zinc with thiosemicarbazone and 3phenylpropenal semicarbazone," Russian Journal of General Chemistry, vol. 76, no. 7, pp. 1100-1105, 2006.

[31] M. S. Bakkar, M. Yamin Siddiqi, and M. S. Monshi, "Preparation and investigation of the bonding mode in the complexes of Pt(II) with thiosemicarbazone ligands," Synthesis and Reactivity in Inorganic, Metal-Organic, and Nano-Metal Chemistry, vol. 33, no. 7, pp. 1157-1169, 2003.

[32] N. Bahrti, F. Naqvi, and A. Azam, "Synthesis, spectral studies and screening for amoebicidal activity of new palladium(II) complexes derived from thiophene-2carboxaldehyde thiosemicarbazones," Bioorganic \& Medicinal Chemistry Letters, vol. 13, no. 4, pp. 689-692, 2003.

[33] J. A. Hickman, "Apoptosis induced by anticancer drugs," Cancer and Metastasis Reviews, vol. 11, no. 2, pp. 121-139, 1992.

[34] J. Chen, Y. Huang, G. Liu, et al., "The cytotoxicity and mechanisms of 1,2-naphthoquinone thiosemicarbazone and its metal derivatives against MCF-7 human breast cancer cells," Toxicology and Applied Pharmacology, vol. 197, no. 1, pp. 40-48, 2004.

[35] N. Gokhale, S. Padhye, D. Rathbone, et al., "The crystal structure of first copper(II) complex of a pyridine-2carboxamidrazone - a potential antitumor agent," Inorganic Chemistry Communications, vol. 4, no. 1, pp. 26-29, 2001. 


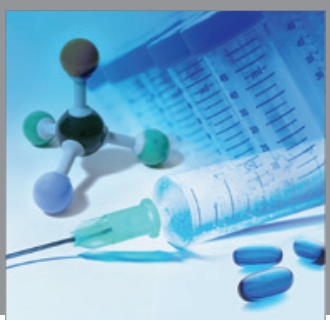

International Journal of

Medicinal Chemistry

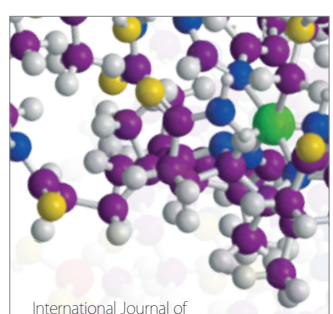

Carbohydrate Chemistry

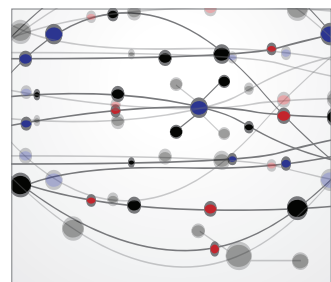

The Scientific World Journal
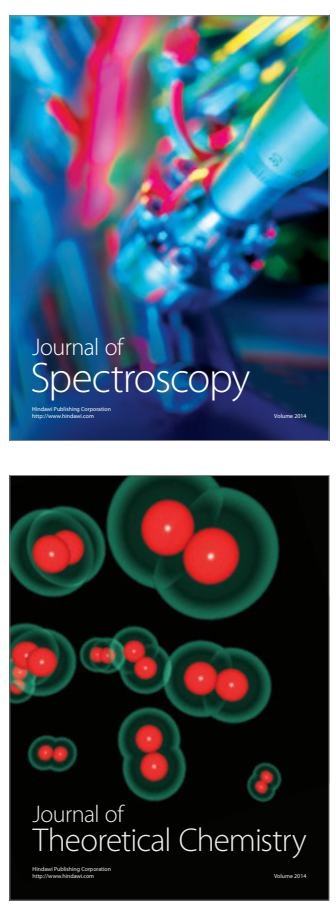
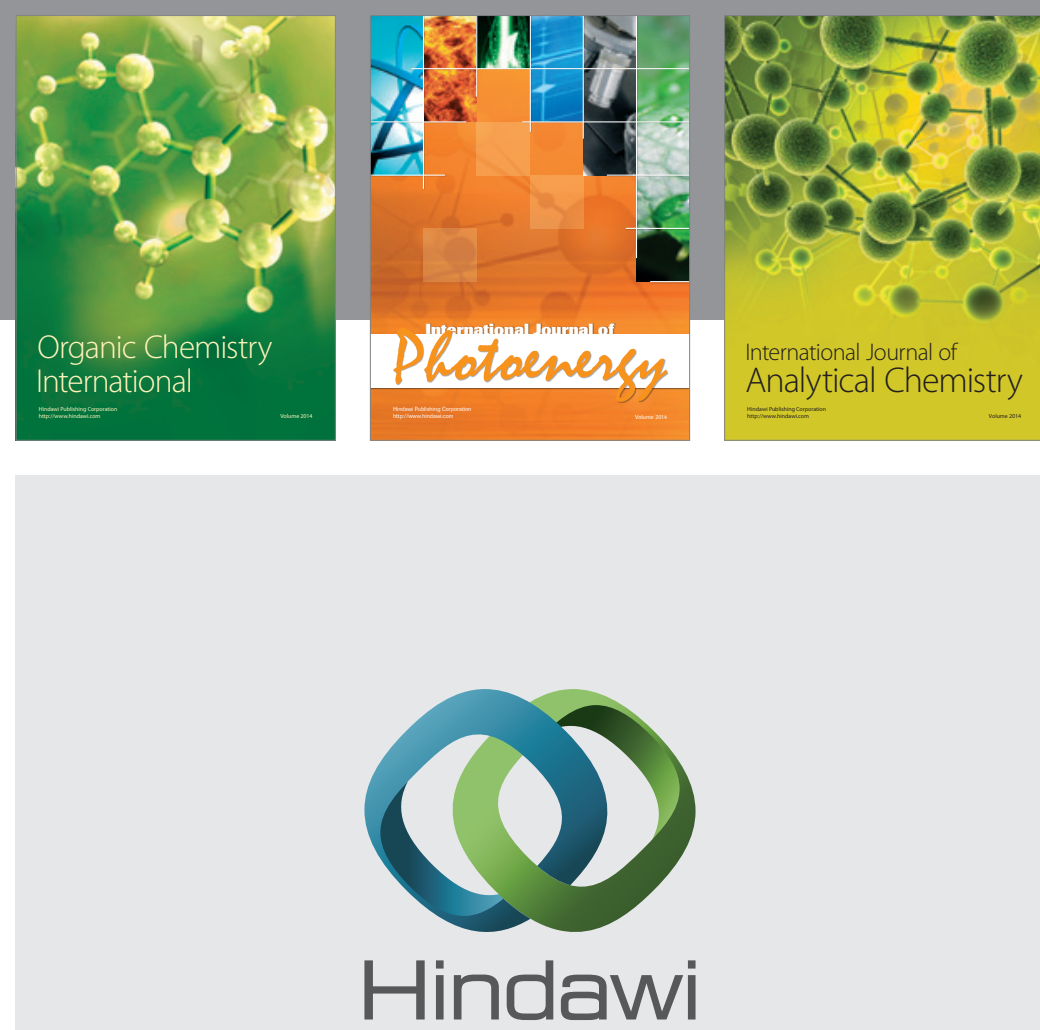

Submit your manuscripts at

http://www.hindawi.com
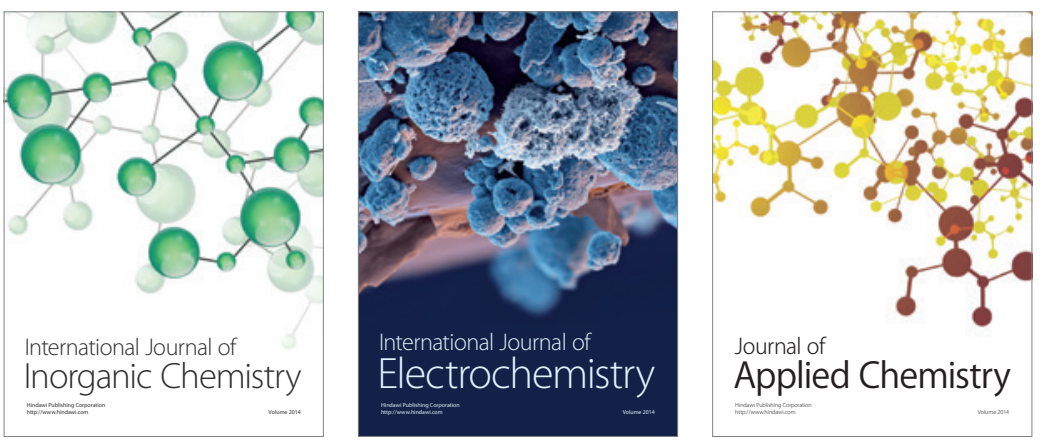

Journal of

Applied Chemistry
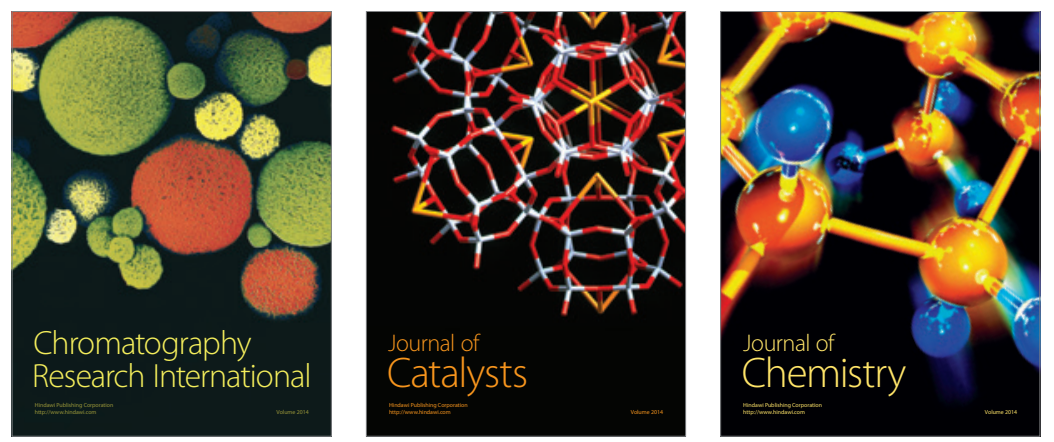
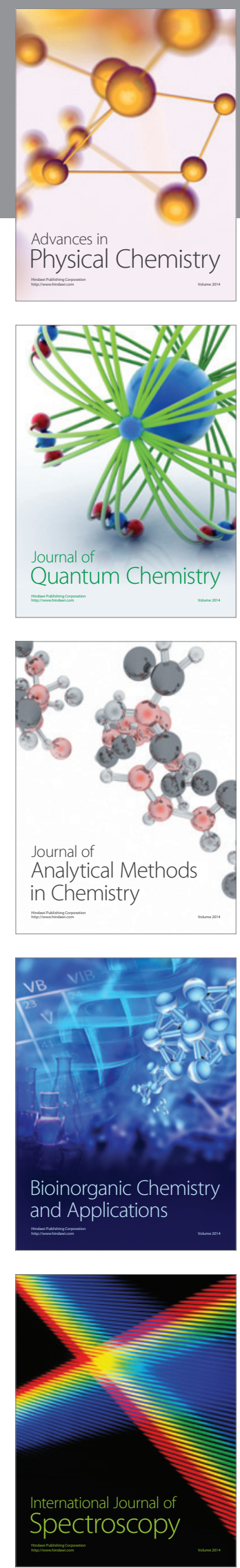